\title{
INFLUENCE OF ROOTSTOCKS ON THE PHYSICAL AND CHEMICAL CHARACTERISTICS OF THE FRUITS AT SOME PLUM CULTIVARS
}

\author{
Bogdan Zamfirescu ${ }^{1}$, Dorel Hoza ${ }^{1}$, Madalina Butac ${ }^{2, *}$, Mihai Chivu ${ }^{2}$ \\ ${ }^{1}$ University of Agronomic Sciences and Veterinary Medicine of Bucharest, \\ 59 Mărăști Blvd, District 1, Bucharest, Romania \\ ${ }^{2}$ Research Institute for Fruit Growing Pitesti, 402 Mărului Street, District Argeș, Pitești, Romania
}

Current Trends in

Natural Sciences

\begin{abstract}
This paper investigated physical and chemical characteristics of five cultivars ('Andreea', 'Piteștean', 'Romanța', 'Čačanska Lepotiča' and 'Jojo') influenced by seven rootstocks ('Mirobolan dwarf', 'Mirodad 1', 'Mirodad 2', 'Adaptabil', 'Redutabil', 'BN4Kr' and 'B83-8'. The trees were planted in 2015 at $4 \times 3 \mathrm{~m}$ and comprised 3 trees / 3 replications. Physical (weight, colour and firmness) and chemical attributes (soluble solids, acid content and pH) were evaluated and calculated. The influence of rootstocks on the fruit's quality was very variable due to complex interactions: rootstock $x$ cultivar, rootstock $x$ year, cultivar $x$ rootstock, cultivar $x$ year. As results of the investigations, we found that some traits such as fruit weight, firmness, soluble solids and acid content of fruits have been influenced by rootstocks. 'Adaptabil' and 'Mirodad 1' rootstocks had a positive effect on some fruit attributes of all plum cultivars studied and can be recommended for extended in commercial orchards.
\end{abstract}

Keywords: cultivar, fruit quality, plum, rootstocks.

\section{INTRODUCTION}

In Romania, European plum (Prunus domestica L.) is one of the most important species, occupying an area of 65,580 hectares and producing 692,670 tons, respectively $5.63 \%$ of the world plum production (Date FAO, 2021). Romania is the third largest producer after China and USA (Butac, 2020).

Plum fruits are a source of minerals and vitamins and contribute to human health (Milošević and Milošević, 2012). Besides the physical characteristics of the fruits (weight, skin colour and firmness), the chemical characteristics of the fruits (soluble solids and acid content) play important role in the use of plums (Bohačenko et al., 2010; Milošević and Milošević, 2012).

It is known that plum quality depend on the cultivar (genetic), environmental conditions, harvest date, orchard management (Nergiz and Yildiz, 1997; Usenik et al., 2008; Milošević and Milošević, 2012), and on the rootstocks. In general, the rootstock influences the growth, yield (Botu et al., 2002; Hrotko et al., 2002; Sosna, 2002; Rubauskis et al., 2003; Kaufmane et al., 2007; Lanauskas, 2006; Sitarek et al., 2007; Vangdal et al., 2007; Butac et al., 2016), but also the fruit size and fruit quality (Kaufmane et al., 2007; Daza et al., 2008; Rato et al., 2008; Milošević and Milošević, 2012; Radovic et al., 2020). 
The most popular rootstock in the plum orchards from Romania is 'Myrobalan' seedling, which is very vigorous, incompatible with some cultivars, causes late bearing and intensive suckering (Botu et al., 2002; Sosna, 2002; Hartman et al., 2007; Blazek and Pistekova, 2009, 2012; Milošević and Milošević, 2012; Butac et al., 2015, 2016; Zamfirescu et al., 2019, 2020). Of this reason, rootstocks suitable for high density orchards are necessary. From this point of view, a lot of vegetative and generative rootstocks have been achieved in Romanian breeding program.

The aim of this paper was to evaluate the influence of seven rootstocks obtained in Romanian breeding program ('Mirobolan dwarf', 'Mirodad 1', 'Mirodad 2', 'Adaptabil', 'Redutabil', 'BN4Kr' and 'B83-8') on the fruit quality characteristics (weight, colour, firmness, soluble solids, acid content and $\mathrm{pH}$ ) of five plum cultivars ('Andreea', 'Piteștean', 'Romanța', 'Čačanska Lepotiča' and 'Jojo').

\section{MATERIALS AND METHODS}

\subsection{Plant material}

The experimental field was carried out in Genetic and Breeding Department of Research Institute for Fruit Growing Pitești-Mărăcineni and included five plum cultivars grafted on seven rootstocks. The orchard was established in 2015. Planting distance was $4 \mathrm{~m}$ between the rows and $3 \mathrm{~m}$ between the trees according to the following experimental scheme:

- Factor A - rootstock with seven graduations: a1 - 'Mirobolan dwarf'; a2 - 'Mirodad 1', a3 'Mirodad 2', a4 - 'Adaptabil', a5 - 'Redutabil', a6 - 'BN4Kr', a7 - 'B83-8';

- Factor B - cultivar with five graduations: b1 - 'Andreea', b2 - 'Piteștean', b3 - 'Romanța', b4 'Čačanska Lepotiča', b5 - 'Jojo';

- Factor C - year, with three graduations: c1 - 2018; c2 - 2019; c3 - 2020.

The experiment was carried out in a randomized block design, in 3 replications with 3 trees per variant.

The trees were trained as open vase, under non-irrigated standard cultural practices.

\subsection{Pedo-climatic conditions}

The experimental field was located on a flat land, of alluvial type, with weak to medium solidified soil, with sandy-loamy - loamy-sandy - loamy texture (NL-LN-L), with groundwater at a depth of 3.5-6.0 meters, with a $\mathrm{pH}$ around 6 . The humus content is relatively low: $1.50 \%$ at the surface, $0.90 \%$ at $60 \mathrm{~cm}$ depth and $0.61 \%$ in the Bg horizon.

During the study period, 2018 - 2020, the annual average temperature was $11.6^{\circ} \mathrm{C}$, being with $1.7^{\circ} \mathrm{C}$ higher than the multiannual average temperature of the area of 51 years (respectively, $9.9^{\circ} \mathrm{C}$ ).

The average annual rainfall was $683.3 \mathrm{~mm}$, ranging between $634.7 \mathrm{~mm}$ in 2019 and $745 \mathrm{~mm}$ in 2018 , being very close to the multiannual average of rainfall from the area $(680 \mathrm{~mm})$.

The relative humidity of the air had an average value lower than the multiannual average $(70.5 \%$ in the study period compared to $75.8 \%$ average value of the last 51 years).

\subsection{Physical and chemical characteristics}

For a period of three harvest seasons, 10 fruits per each tree of cultivar/rootstock combination in three replications were collected and the following physical and chemical attributes were evaluated:

- the fruit weight was recorded with a balance in $\mathrm{g} /$ fruit;

- the fruit skin colour parameters (L, a, b) were measured using a Konica Minolta CR 400 chromameter, where $\mathrm{L}$ corresponds to Luminance, and $\mathrm{a}$ and $\mathrm{b}$ to the chromaticity coordinates. The CIELAB colour scale is an approximately uniform color scale. In a uniform color scale, the differences between points plotted in the color space correspond to visual differences between the 
colours plotted. The CIELAB colour scale is organized in a cube form. The $\mathrm{L}^{*}$ axis runs from top to bottom. The maximum for $\mathrm{L}^{*}$ is 100 , which represents a perfect reflecting diffuser. The minimum for $\mathrm{L}^{*}$ is zero, which represents black. The $\mathrm{a}^{*}$ and $\mathrm{b}^{*}$ axes have no specific numerical limits. Positive $a^{*}$ is red. Negative $a^{*}$ is green. Positive $b^{*}$ is yellow. Negative $b^{*}$ is blue;

- the fruit firmness was measured with non-destructive penetrometer Qualitest HPE equipped with a plunger of diameter $0.10 \mathrm{~cm}^{2}$.

- soluble solids contents of fruits was measured with Digital Sucrose Refractometer - (Hanna Instrument 96801), in \% Brix;

- the fruit $\mathrm{pH}$ and malic, citric and tartaric acid was measured using the device Minititrator and $\mathrm{pH}$ meter for fruit juice - Hanna Instrument 84532. Titratable acidity is expressed as $\% \mathrm{or} g / 100 \mathrm{~g}$ fresh matter.

\subsection{Statistical analysis}

A $7 \times 5 \times 3$ factorial design, that included 7 rootstocks, 5 cultivars and 3 years, was employed.

For the statistical interpretation of the results, the data were included in an Excel database and then statistically interpreted with the SPSS 14.0 program, which uses the Duncan test (multiple t test) for a 5\% statistical assurance. The relationship between physical and chemical characteristics was evaluated by Pearson's correlation at $\mathrm{P} \leq 0.05$.

\section{RESULTS AND DISCUSSIONS}

\subsection{Fruit weight.}

Usually, plum rootstocks have not significant effect on fruit weight (Hrotko et al., 2002; Sosna, 2002; Lanauskas, 2006). Statistical analysis of data on fruit weight, show that, between cultivar/rootstocks combinations were not significant differences. The largest fruits were obtained on 'Adaptabil' (50.10 g) and 'Mirodad 1' (48.93 g) rootstocks. Regarding cultivar, the significantly higher fruit weight was obtained at 'Romanța' (60.78 g) and 'Jojo' (52.58 g) cvs. and lower at 'Čačanska Lepotiča' cv. (39.25 g). The fruit weight was significantly higher in 2020 than 2019 and 2018. The best combinations cultivar/rootstock were: 'Romanța/Mirodad 1' (66.80 g $)$, 'Romanța/Adaptabil' (66.34 g), 'Romanța/ Mirobolan dwarf' (64.98 g), 'Jojo/Mirobolan dwarf' (54.09 g), 'Jojo/BN4Kr' (53.94 g) and 'Jojo/Adaptabil' (52.91 g) (Table 1).

The same results were reported by Milošević and Milošević (2012) at 'Čačanska Lepotiča' cv. grafted on 'Myrobalan' and 'Stanley' seedlings.

\subsection{Fruit firmness.}

Firmness is an important factor in stone fruits being in correlation with taste and shelf life. Firmness assessment is used both in the marketing chain to appreciate fruit quality and by researchers in cultivars testing and in breeding programs regarding fruit quality (Sekse and Wermund, 2010). Generally, fruits firmness decreases during the maturation and ripening. Early plum cultivars are usually less firm than late cultivars (Crisosto, 1994).

Statistical analysis of data on fruit firmness, show that, between cultivar/rootstocks combinations were some significant differences. The higher fruits firmness was obtained on 'Adaptabil' (57.49 HPE units) and 'Mirodad 1' (56.87 HPE units) rootstocks. Regarding cultivar, the significantly higher fruit firmness was obtained at 'Jojo' cv. (61.26 HPE units) and lower at 'Romanța' cv. (52.22 HPE units). The fruit firmness was significantly higher in 2020 than 2019 and 2018. The best combinations cultivar/rootstock was: 'Jojo/BN4Kr' (65.19 HPE units), 'Jojo/Mirodad 2' (65.29 HPE units), 'Jojo/Mirodad 1' (60.41 HPE units) (Table 1). 


\section{Current Trends in Natural Sciences}

Vol. 10, Issue 20, pp. 157-164, 2021

https://doi.org/10.47068/ctns.2021.v10i20.021

Current Trends in Natural Sciences (on-line)

ISSN: 2284-953X

Current Trends in Natural Sciences (CD-Rom)

ISSN: 2284-9521

ISSN-L: 2284-9521

ISSN-L: 2284-9521

Given the classification made by Vangdal and Flatland (2010) in five maturation groups according to the fruit firmness, plum cultivars studied were grouped into group 4 (firmness 50-59 HPE units, respectively $4-6 \mathrm{kgcm}^{-2}$ ) - eating ripe (the fruit should be immediately picked and marketed) and group 3 (firmness 60-69 HPE units, respectively $6-7 \mathrm{kgcm}^{-2}$ ) - tree ripe (optimum maturity stage for picking).

3.3. Fruits colour. Skin colour is an important external feature of the fruit being one of the criteria used in buying fruits. In many fruit species, when fruits ripen the background colour turns from green to yellow and fruit flavor improves. This means that fruit colour provides information about taste. To appreciate the fruit colour of cultivar/rootstock combinations we are using Konica Minolta chromameter. According to the CIELAB colour scale it is noted that, there are significant differences between cultivars. It is known that, when approaching of optimum maturity, cultivars become more lightness $(\mathrm{L} *)$, redder $(\mathrm{a} *)$ and bluer $(\mathrm{b} *)$ (Vangdal and Flatland, 2010).

Table 1. The influence of seven rootstocks on fruits physical characteristics on five plum cultivars

\begin{tabular}{|c|c|c|c|c|c|}
\hline \multirow[t]{2}{*}{ Parameter } & \multirow[t]{2}{*}{ Fruit weight (g) } & \multirow{2}{*}{$\begin{array}{c}\text { Firmness (HPE } \\
\text { units) }\end{array}$} & \multicolumn{3}{|c|}{ Colour parametters $(L, a, b)$ Konica Minolta } \\
\hline & & & $L^{*}$ & $a^{*}$ & $b^{*}$ \\
\hline \multicolumn{6}{|l|}{ Rootstock (A) } \\
\hline Mirobolan dwarf & $48.73 a$ & $55.77 a$ & $25.81 a$ & $3.35 a$ & $-0.86 a b$ \\
\hline Mirodad 1 & $48.93 a$ & $56.87 a$ & $26.82 a$ & $3.15 a$ & $-0.32 a$ \\
\hline Mirodad 2 & $48.31 a$ & $55.87 a$ & $25.70 a$ & $2.82 a$ & $-1.88 b$ \\
\hline Adaptabil & $50.10 a$ & $57.49 a$ & $25.79 a$ & $3.18 a$ & $-1.37 a b$ \\
\hline Redutabil & $41.68 \mathrm{~b}$ & $51.83 a$ & $25.26 a$ & $2.66 a$ & $-1.57 a b$ \\
\hline$B N 4 K r$ & $48.75 a$ & $55.44 a$ & $25.07 a$ & $3.66 a$ & $-0.83 b$ \\
\hline B 83-8 & $46.91 a$ & $54.71 a$ & $27.08 a$ & $3.55 a$ & $-0.86 a b$ \\
\hline \multicolumn{6}{|l|}{ Cultivar (B) } \\
\hline Andreea & $42.92 c$ & $55.93 \mathrm{~b}$ & $29.61 a$ & $6.78 a$ & $1.11 a$ \\
\hline Pitestean & $42.63 c$ & $53.54 \mathrm{~b}$ & $25.43 c$ & $1.97 \mathrm{~cd}$ & $-1.10 b$ \\
\hline Romanta & $60.78 a$ & $52.22 \mathrm{~b}$ & $25.03 c$ & $3.01 \mathrm{~b}$ & $-1.93 b$ \\
\hline $\begin{array}{l}\text { Cacanska } \\
\text { Lepotica }\end{array}$ & $39.25 d$ & $54.20 \mathrm{~b}$ & $26.93 \mathrm{~b}$ & $1.62 d$ & $-3.31 c$ \\
\hline Jojo & $52.58 \mathrm{~b}$ & $61.26 a$ & $23.38 d$ & $2.46 b c$ & $-0.98 b$ \\
\hline \multicolumn{6}{|l|}{$\operatorname{Year}(C)$} \\
\hline 2018 & $47.91 a b$ & $52.45 \mathrm{~b}$ & $24.67 b$ & $2.82 \mathrm{~b}$ & $-1.34 a$ \\
\hline 2019 & $46.06 \mathrm{~b}$ & $49.86 \mathrm{~b}$ & $26.73 a$ & $2.39 \mathrm{~b}$ & $-1.47 a$ \\
\hline 2020 & $48.92 a$ & $64.09 a$ & $26.82 a$ & $4.30 a$ & $-0.91 a$ \\
\hline$A x B$ & $n s$ & $*$ & $n s$ & $n s$ & $n s$ \\
\hline$B x A$ & $n s$ & $*$ & $*$ & $*$ & $*$ \\
\hline$A x C$ & $*$ & $n s$ & $*$ & $*$ & $*$ \\
\hline$C x A$ & $*$ & $*$ & $*$ & $*$ & $*$ \\
\hline$B x C$ & $n s$ & $n s$ & $n s$ & $n s$ & $n s$ \\
\hline$C x B$ & $n s$ & $n s$ & $n s$ & $n s$ & $n s$ \\
\hline
\end{tabular}

Different letter(s) in columns indicate significantly different values at $\mathrm{P} \leq 0.05$ by Duncan test. The asterisk in column indicates significant differences between means at $\mathrm{P} \leq 0.05$ by Duncan test. ns: non-significant differences.

The values for L* ranging between 23.38 ('Jojo' cv.) and 29.61 ('Andreea' cv.), values which situated varieties on $\mathrm{L}^{*}$ axis closer to black colour. The most colorful fruits were obtained in the case of the 'BN4Kr' rootstock $\left(\mathrm{L}^{*}=25.07\right)$, and the least colored in the case of the ' $\mathrm{B}$ 83-8' rootstock $\left(\mathrm{L}^{*}=27.08\right)$. During the three years of study, the most colorful fruits were obtained in $2018\left(\mathrm{~L}^{*}=24.67\right)$, and the least colored in $2020\left(\mathrm{~L}^{*}=26.82\right)($ Table 1$)$. 


\section{Current Trends in Natural Sciences}

Vol. 10, Issue 20, pp. 157-164, 2021

https://doi.org/10.47068/ctns.2021.v10i20.021

Current Trends in Natural Sciences (on-line)

ISSN: 2284-953X

Current Trends in Natural Sciences (CD-Rom)

ISSN: 2284-9521

ISSN-L: 2284-9521

ISSN-L: 2284-9521

Regarding axis $\mathrm{a}^{*}$, values obtained show that there are significant differences between cultivars. The highest values of $\mathrm{a}^{*}$ occurring at 'Andreea' $\mathrm{cv} .\left(\mathrm{a}^{*}=6.78\right.$ - reddish colour of the fruits) and lowest at 'Čačanska Lepotiča' cv., ( $\mathrm{a}^{*}=1.62$ - dark blue fruits). The most colorful fruits were obtained in the case of the 'Redutabil' rootstock $\left(\mathrm{a}^{*}=2.66\right)$, and the least colored in the case of the 'Bn4Kr' rootstock $\left(\mathrm{a}^{*}=3.66\right)$. During the three years of study, the most colorful fruits were obtained in $2019\left(\mathrm{a}^{*}=2.39\right)$, and the least colored in $2020\left(\mathrm{a}^{*}=4.30\right)($ Table 1$)$.

On axis $b *$ is found also that there are significant differences between cultivars. The highest value (positive) has 'Andreea' cv. $\left(b^{*}=1.11\right)$, which have reddish fruits, and the lowest value (negative) occurring at 'Čačanska Lepotiča' cv. ( $b^{*}=-3.31$ ), which has dark blue fruits. The most colorful fruits were obtained in the case of the 'Mirodad 2' rootstock $\left(b^{*}=-1.88\right)$, and the least colored in the case of the 'Mirodad 1' rootstock $\left(b^{*}=-0.32\right)$. During the three years of study, the most colorful fruits were obtained in $2019\left(b^{*}=-1.47\right)$, and the least colored in $2020\left(b^{*}=-0.91\right)$ (Table 1$)$.

3.4. Soluble solids and acid content of the fruits.

There are significant differences among cultivar/rootstock combination in soluble solids content of the fruits. Year by year variation of soluble solids was no significant but was higher in 2019 than 2018 and 2020. The effect of the rootstocks on the soluble solids content of the fruits was not detectable. In our study, 'Adaptabil' and 'Bn4Kr', which are high vigour rootstocks, produced fruits with low soluble solids content (14.85\% Brix in case of 'Adaptabil' rootstock and $14.78 \%$ Brix in case of 'BN 4Kr' rootstock) (Table 2).

Table 2. The influence of seven rootstocks on fruits chemical characteristics on five plum cultivars

\begin{tabular}{|c|c|c|c|c|c|}
\hline \multirow[t]{2}{*}{ Parameter } & \multirow{2}{*}{$\begin{array}{c}\text { Soluble solids } \\
\text { content (\% Brix) }\end{array}$} & \multirow[t]{2}{*}{$p H$} & \multicolumn{3}{|c|}{ Acid content (\%) } \\
\hline & & & Malic acid & Citric acid & Tartaric acid \\
\hline \multicolumn{6}{|l|}{ Rootstock $(A)$} \\
\hline Mirobolan dwarf & $15.07 a$ & $4.50 a$ & $0.52 a$ & $0.49 a$ & $0.56 a$ \\
\hline Mirodad 1 & $15.44 a$ & $4.51 a$ & $0.52 a$ & $0.50 a$ & $0.56 a$ \\
\hline Mirodad 2 & $15.14 a$ & $4.45 a$ & $0.52 a$ & $0.50 a$ & $0.56 a$ \\
\hline Adaptabil & $14.85 a$ & $4.52 a$ & $0.53 a$ & $0.51 a$ & $0.57 a$ \\
\hline Redutabil & $15.47 a$ & $4.62 a$ & $0.46 a$ & $0.44 a$ & $0.50 a$ \\
\hline$B N 4 K r$ & $14.78 a$ & $4.60 a$ & $0.52 a$ & $0.49 a$ & $0.54 a$ \\
\hline B 83-8 & $15.11 a$ & $4.46 a$ & $0.53 a$ & $0.50 a$ & $0.57 a$ \\
\hline \multicolumn{6}{|l|}{ Cultivar $(B)$} \\
\hline Andreea & $17.68 a$ & $5.05 a$ & $0.50 \mathrm{~b}$ & $0.48 \mathrm{~b}$ & $0.54 a$ \\
\hline Pitestean & $13.59 d$ & $4.65 \mathrm{~b}$ & $0.49 \mathrm{~b}$ & $0.47 \mathrm{~b}$ & $0.53 a$ \\
\hline Romanta & $14.29 c$ & $4.41 c$ & $0.57 a$ & $0.55 a$ & $0.62 a$ \\
\hline $\begin{array}{l}\text { Cacanska } \\
\text { Lepotica }\end{array}$ & $14.64 c$ & $4.34 c d$ & $0.39 c$ & $0.36 \mathrm{~b}$ & $0.42 a$ \\
\hline Jojo & $15.42 \mathrm{~b}$ & $4.16 d$ & $0.62 a$ & $0.60 a$ & $0.66 a$ \\
\hline \multicolumn{6}{|l|}{$\operatorname{Year}(C)$} \\
\hline 2018 & $15.26 a$ & $4.47 a$ & $0.37 a$ & $0.35 c$ & $0.41 a$ \\
\hline 2019 & $15.63 a$ & $4.23 a$ & $0.42 \mathrm{~b}$ & $0.40 \mathrm{~b}$ & $0.46 a$ \\
\hline 2020 & $14.49 a$ & $4.88 a$ & $0.75 a$ & $0.72 a$ & $0.80 a$ \\
\hline$A x B$ & $n s$ & $n s$ & $*$ & $*$ & $*$ \\
\hline$B x A$ & $*$ & $*$ & $*$ & $*$ & $*$ \\
\hline$A x C$ & $*$ & $n s$ & $n s$ & $n s$ & $n s$ \\
\hline$C x A$ & $*$ & $*$ & $*$ & $*$ & $*$ \\
\hline$B x C$ & $n s$ & $n s$ & $n s$ & $n s$ & $N s$ \\
\hline$C x B$ & $n s$ & $n s$ & $n s$ & $n s$ & $n s$ \\
\hline
\end{tabular}

Different letter(s) in columns indicate significantly different values at $\mathrm{P} \leq 0.05$ by Duncan test. The asterisk in column indicates significant differences between means at $\mathrm{P} \leq 0.05$ by Duncan test. ns: non-significant differences. 


\section{Current Trends in Natural Sciences}

Vol. 10, Issue 20, pp. 157-164, 2021

https://doi.org/10.47068/ctns.2021.v10i20.021

Current Trends in Natural Sciences (on-line)

ISSN: 2284-953X

Current Trends in Natural Sciences (CD-Rom)

ISSN: 2284-9521

ISSN-L: 2284-9521

ISSN-L: 2284-9521

Sitarek and co-authors (2007) in a previous study showed that soluble solids content of the fruits were not affected by rootstocks and Usenik and co-workers (2008) reported that cultivars influenced on soluble solids content of the fruits, which is like the results in our study. Daza and coauthors (2008) reported that rootstocks with high vigour produced fruits with low soluble solids content.

The differences in plum acid content significantly varied between cultivars and years, but differences between rootstocks were insignificant. These results are similar with other results obtained by Sitarek et al. in 2007 and Milošević and Milošević in 2012. The highest acid content was obtained in 2020 (0.75\% malic acid, $0.72 \%$ citric acid and $0.80 \%$ tartaric acid) and lowest in 2018 ( $0.37 \%$ malic acid, $0.35 \%$ citric acid and $0.41 \%$ tartaric acid) (Table 2 ).

Effect of rootstocks and year on the fruit's $\mathrm{pH}$ was not found, but effect of cultivars on the fruit's $\mathrm{pH}$ was found. Some authors report that the $\mathrm{pH}$ of fruits has values between 3 and 3.5 (Paunovic et al., 1977; Janda and Gavrilović, 1984; Milošević and Milošević, 2012). In our study, the values of fruits pH ranged between 4.16 ('Jojo' cv.) and 5.05 ('Andreea' cv.) (Table 2).

Minas et al. (2015) has found that plums were harvested when soluble solids content was 11.1$19.7 \%$ and acid content varied from 0.30 to $1.60 \%$.

\subsection{Correlations between fruit quality characteristics.}

Comparing the physical and chemical characteristics of the fruits, some significant correlations were found. For example, fruit weight was negatively correlated with colour $(r=-0.258-$ in case of Luminance) and positively with firmness $(\mathrm{r}=0.115)$ and malic, citric and tartric acid content $(\mathrm{r}=$ 0.328). These correlations indicate that large fruits are less colored, but firmer and more acidic. Correlation between fruit weight and soluble solids content of fruits were not found (Table 3 ).

Table 3. Correlation matrix among variables studied

\begin{tabular}{|c|c|c|c|c|c|c|c|c|c|c|}
\hline Variable & $F W$ & $L^{*}$ & $a^{*}$ & $b^{*}$ & $F$ & $S S$ & $p H$ & MA & $C A$ & $T A$ \\
\hline$F W$ & 1 & $\begin{array}{c}-0.258 \\
(* *)\end{array}$ & 0.008 & 0.004 & $\begin{array}{c}0.115 \\
(*)\end{array}$ & -0.104 & -0.108 & $\begin{array}{c}0.328 \\
(* *)\end{array}$ & $\begin{array}{c}0.329 \\
(* *)\end{array}$ & $\begin{array}{c}0.330 \\
(* *)\end{array}$ \\
\hline$L^{*}$ & & 1 & $\begin{array}{c}0.247 \\
(* *)\end{array}$ & $\begin{array}{c}0.148 \\
(* *)\end{array}$ & -0.076 & $\begin{array}{c}0.240 \\
(* *)\end{array}$ & $\begin{array}{c}0.224 \\
(* *)\end{array}$ & -0.016 & -0.014 & -0.017 \\
\hline$a^{*}$ & & & 1 & $\begin{array}{c}0.392 \\
(* *)\end{array}$ & $\begin{array}{c}0.234 \\
(* *)\end{array}$ & $\begin{array}{c}0.247 \\
(* *)\end{array}$ & $\begin{array}{c}0.361 \\
(* *)\end{array}$ & $\begin{array}{c}0.286 \\
(* *)\end{array}$ & $\begin{array}{c}0.287 \\
(* *)\end{array}$ & $\begin{array}{c}0.288 \\
(* *)\end{array}$ \\
\hline$b^{*}$ & & & & 1 & $\begin{array}{c}0.155 \\
(* *)\end{array}$ & 0.100 & $\begin{array}{c}0.227 \\
(* *)\end{array}$ & $\begin{array}{c}0.145 \\
(*)\end{array}$ & $\begin{array}{c}0.147 \\
(* *)\end{array}$ & $\begin{array}{c}0.148 \\
(* *)\end{array}$ \\
\hline$F$ & & & & & 1 & $\begin{array}{c}-0.114 \\
(*)\end{array}$ & 0.035 & $\begin{array}{c}0.607 \\
(* *)\end{array}$ & $\begin{array}{c}0.606 \\
(* *)\end{array}$ & $\begin{array}{c}0.608 \\
(* *)\end{array}$ \\
\hline$S S$ & & & & & & 1 & $\begin{array}{c}0.172 \\
(* *)\end{array}$ & $\begin{array}{c}-0.197 \\
(* *)\end{array}$ & $\begin{array}{c}-0.196 \\
(* *)\end{array}$ & $\begin{array}{c}-0.198 \\
(* *)\end{array}$ \\
\hline$p H$ & & & & & & & 1 & $\begin{array}{c}0.115 \\
(*)\end{array}$ & $\begin{array}{c}0.118 \\
(*)\end{array}$ & $\begin{array}{c}0.119 \\
(*)\end{array}$ \\
\hline$M A$ & & & & & & & & 1 & $\begin{array}{c}0.999 \\
(* *)\end{array}$ & $\begin{array}{c}0.999 \\
(* *)\end{array}$ \\
\hline$C A$ & & & & & & & & & 1 & $\begin{array}{c}0.997 \\
(* *)\end{array}$ \\
\hline$T A$ & & & & & & & & & & 1 \\
\hline
\end{tabular}

Abbreviations: FW - fruit weight; L*a*b* - colour parameters; F - firmness; $\mathrm{SS}$ - soluble solids; $\mathrm{pH}$ - pH value; MA - malic acid; CA - citric acid; TA - tartaric acid. ** Correlation is significant at the 0.01 level (2-tailed); *Correlation is significant at the 0.05 level (2-tailed). 
We, also, found some significant correlations between colour parameters and soluble solids content of the fruits $\left(\mathrm{r}=0.240\right.$ for $\mathrm{L}^{*}$ parameter and $\mathrm{r}=0.247$ for $\mathrm{a}^{*}$ parameter $), \mathrm{pH}(\mathrm{r}=0.224$ for $\mathrm{L}^{*}$ parameter, $\mathrm{r}=0.361$ for $\mathrm{a}^{*}$ parameter and $\mathrm{r}=0.227$ for $\mathrm{b}^{*}$ parameter) and acid content (e.g., $\mathrm{r}=$ 0.286 for $\mathrm{a}^{*}$ parameter and $\mathrm{r}=0.145$ for $\mathrm{b}^{*}$ parameter), which indicates that more colorful fruits have a balanced taste. There are negatively correlations between fruit firmness and soluble solids content $(\mathrm{r}=-0.114)$ and positively correlations between fruit firmness and acid content of fruits $(\mathrm{r}=$ 0.607 - malic acid, $r=0.606-$ citric acid and $r=0.608-$ tartaric acid), which indicates that firmer fruits are more acidic. There are positively correlations between soluble solids and acid content of fruits $(\mathrm{r}=0.172-\mathrm{pH}, \mathrm{r}=0.197-$ malic acid, $\mathrm{r}=0.196-$ citric acid and $\mathrm{r}=0.198$ tartaric acid) (Table 3).

\section{CONCLUSIONS}

The influence of rootstocks on the fruit's quality was very variable due to complex interactions: rootstock $\mathrm{x}$ cultivar, rootstock $\mathrm{x}$ year, cultivar $\mathrm{x}$ rootstock, cultivar $\mathrm{x}$ year.

As results of the investigations, we found that some traits, such as fruit weight, firmness and soluble solids content of fruits have been slowly influenced by rootstocks.

The results showed that:

- 'Mirodad 1' rootstock had a positive effect on the fruit weight, firmness and soluble solids content of all plum cultivars studied;

- 'Adaptabil' rootstock had a positive effect on the fruit weight, firmness, and acid content.

These two rootstocks can be recommended for extended in commercial orchards, given their positive influence on plum cultivars regarding other traits presented in other study, such as yield and trees vigour.

\section{REFERENCES}

Blažek, J., Pištěková, I. (2009). Preliminary evaluation results of new plum cultivars in a dense planting. Hort. Sci. (Prague), 36 (2), 45-54.

Blažek, J., Pištěková, I. (2012). Initial results from the evaluation of plum cultivars grown in a very dense planting. Acta Hort., 968, 99-108.

Bohačenko, I., Pinkrová, J., Komárková, J., Paprštein, F. (2010). Selected processing characteristics of new plum cultivars grown in the Czech Republic. Hortic Sci., 37, 39-45.

Botu, I., Achim, G., Botu, M., Godeanu, I., Baciu, A. (2002). The evaluation and classification of growth vigour of the plum cultivars grafted on various rootstocks. Acta Hort., 577, 299-306.

Butac, M. (2020). Plum breeding. In: Prunus. Intech Open, London, United Kingdom (Open Access books).

Butac, M., Chitu, E., Militaru, M., Sumedrae, M., Sumedrea, D., Plopa, C. (2015). Orchards performance of some Romanian plum cultivars grafted on two rootstocks. Agriculture and Agricultural Science Procedia 6 (2015), Elsevier, 118-123.

Butac, M., Dutu, I., Mazilu, Cr., Sumedrea, D., Militaru, M., Cojocaru, M., Zamfirescu, B., Coman, R., 2016. Preliminary results regarding the influence of the rootstocks to the vigour and precocity of some plum cultivars. Fruit Growing Research, Vol. XXXII, 71-76.

Crisosto, C. (1994). Stone fruit maturity indices: a descriptive review. Postharvest News and Information 1994, Vol. 5 No. $6,65 \mathrm{~N}-68 \mathrm{~N}$.

Daza, A., Garcia-Galavis, M.G., Echeverria, G., Puy, J. (2007). Fruit quality parameters of Pioneer Japanese plums produced on eight different rootstocks. Sci. Hort., 118, 206-211.

Hartman, W., Kosina, J., Paszko, D., Beuschlein, H.D., Ogasanovic, D. (2007). Rootstocks in plum growing - Results of an international rootstock trial. Acta Hort., 734, 141-148.

Hrotko K., Magyar L., Klenyin T., Simon G. (2002). Effect of different rootstocks on growth and yield efficiency of plum cultivars. Acta Hort., 577, 105-110. 


\section{Current Trends in Natural Sciences}

Vol. 10, Issue 20, pp. 157-164, 2021

https://doi.org/10.47068/ctns.2021.v10i20.021

Current Trends in Natural Sciences (on-line)

ISSN: 2284-953X

Current Trends in Natural Sciences (CD-Rom)

ISSN: 2284-9521

ISSN-L: 2284-9521

ISSN-L: 2284-9521

Janda, L. Gavrilović, J. (1984). Komparativna proučavanja vrednosti ploda u novith sorti šljiva. (A comparative study of the value of new varieties of plums). Jug. Voćarstvo, 18, 493-498.

Kaufmane, E., Rubauskis, E., Skrivele, M. (2007). Influence of different rootstocks on the growth and yield of plum cultivars. Acta Hort., 734, 387-391.

Kaufmane, E., Skrivele, M., Rubauskis, E., Ikase L. (2007). The yield and fruit quality of two plum cultivars on different rootstocks. Scientific works of the Lithuanian Institute of Horticulture and Lithuanian University of Agriculture, 26 (3), 10-15.

Lanauskas, J. (2006). Effect of rootstock on growth and yield of plum tree cvs. 'Stanley' and 'Kauno Vengrine'. Scientific works of the Lithuanian Institute of Horticulture and Lithuanian University of Agriculture, 25 (3), 243249.

Milošević, T. and Milošević, N. (2012). The physical and chemical attributes of plum influenced by rootstock. Acta Alimentaria, vol. 41 (3), 293-303.

Minas, S.I., Forcada, C.F, Dangl, S.G., Gradziel, M.T., Dandekar, M.A., Crisosto, H.C. (2015). Discovery of nonclimacteric and suppressed climacteric bud sport mutations originating from a climacteric Japanese plum cultivar (Prunus salicina Lindl.). Frontiers in lant Science, 12 May 2015/http:dx.doi.org.

Nergiz, C., Yildiz, H. (1997). Research on chemical composition of some varieties of European plum (Prunus domestica) adapted to the Aegean district of Turkey. J. Agric. Fd. Chem., 45, 2820-2823.

Paunović, S.A., Gavrilović, M., Ogašanović, D. (1977). Some more important biological and economic properties of new cultivars and hybrids of plums obtained at the Research Institute at Čačak. Acta Hort., 74, 143-153.

Radović, M., Milatović, D., Tešić, Z., Tosti, T., Gašić, U., Dojčinović, B., Dabić, Zagorac D. (2020). Influence of rootstocks on the chemical composition of the fruits of plum cultivars. Journal of Food Composition and Analysis, Vol. 92.

Rato, E.A., Agulheiro, C.A., Barroso, M.J., Riquelme, F. (2008). Soil and rootstock influence on fruit quality of plums (Prunus domestica L.). Sci. Hort., 118, 218-222.

Rubauskis, E., Skrivele, M., Dimza, I. (2003). Growth and yielding of plum trees in experiment with fertigation and rootstock. Agronomijas Vestis, no. 5, 59-65.

Sekse, L. and Wermund, U. (2010). Fruit flesh firmness in two plum cultivars: comparison of two penetrometers. Acta Hort., 874, 119-124.

Sitarek, M., Grzyb, Z.S., Kozinski, B. (2007). Effect of four different rootstocks on the growth, yield and fruit quality of 'Valor' plum trees. Acta Hort., 734, 413-416.

Sosna, I. (2002). Growth and cropping of four plum cultivars on different rootstocks in South Western Poland. Journal of Fruit and Ornamental Plant Research, Vol. X, 95-103.

Usenik, V., Kastelec, D., Veberič, R., Štampar, F. (2008). Quality changes during ripening of plums (Prunus domestica L.). Fd. Chem., 111, 830-836.

Vangdal, E., Doving, A., Mage, F. (2007). The fruit quality of plums (Prunus domestica L.) as related to yield and climatic conditions. Acta Hort., 734, 425-429.

Vangdal, E., Flatland, S.B. (2010). Criteria for picking plums (Prunus domestica L.) at the optimum maturity stage for the fresh fruit market. Acta Hort. 874, 125-130.

Zamfirescu, B., Hoza, D., Butac, M., Nicolae, S., Mazilu, Cr., Chițu, E., Sumedrea, D., Militaru, M., Chivu, M. (2019). Orchard performance of some plum cultivars grafted on different rootstocks. Scientific papers, Series B, Horticulturae, vol. LXIII, no. 1, 149-153.

Zamfirescu, B., Hoza, D., Butac, M., Chivu, M. (2020). Influence of some rootstocks on the growth, yield and fruits quality at the 'Jojo' plum cultivar. Scientific papers, Series B, Horticulturae, vol. LXIV, no. 1, 210-214.

***. (2021). FAO Statistics Division. https://www.fao.org/faostat/en/\#data/QCL 